Article

\title{
Effect of supports on the structure and activity of vanadium-chromium oxide catalysts for ammoxidation of 3-picoline
}

\author{
Feng Jiang a, Shengcai Deng b, Lei Niu a, Guomin Xiao a,* \\ a School of Chemistry and Chemical Engineering, Southeast University, Nanjing 211189, Jiangsu, China \\ ${ }^{\mathrm{b}}$ Key Laboratory of Mesoscopic Chemistry of MOE, Jiangsu Provincial Key Laboratory of Nanotechnology, School of Chemistry and Chemical \\ Engineering, Nanjing University, Nanjing 210093, Jiangsu, China
}

\section{A R T I C L E I N F O}

\section{Article history:}

Received 7 June 2013

Accepted 2 July 2013

Published 20 October 2013

\section{Keywords:}

Ammoxidation

3-Picoline

Nicotinonitrile

Support

Vanadium-chromium oxide

\begin{abstract}
A B S T R A C T
Bulk and $\mathrm{Nb}_{2} \mathrm{O}_{5}-, \mathrm{MgF}_{2}-, \mathrm{TiO}_{2}$, and $\mathrm{SiO}_{2}$-supported vanadium-chromium oxide catalysts were prepared by the incipient wetness impregnation method and investigated for the ammoxidation of 3-picoline to nicotinonitrile at $310-400{ }^{\circ} \mathrm{C}$. The physical and chemical properties of the catalysts were assessed by X-ray diffraction, $\mathrm{N}_{2}$ adsorption-desorption, $\mathrm{H}_{2}$-temperature-programmed reduction, and $\mathrm{NH}_{3}$-temperature-programmed desorption. The surface area of the supports influenced the formation of the active components of the catalysts: high surface area encouraged the formation of monoclinic $\mathrm{CrVO}_{4}$ whereas low surface area favored the formation of orthorhombic $\mathrm{CrVO}_{4}$. The high reducibility of vanadium in the catalyst and the large number of surface active sites resulted in higher 3-picoline conversion efficiencies. The high selectivity was attributed to the low surface acidity of the catalysts. Reaction temperature showed a positive effect on the catalytic performance for it could increase 3-picoline conversion and maintain nicotinonitrile selectivity.
\end{abstract}

(C) 2013, Dalian Institute of Chemical Physics, Chinese Academy of Sciences. Published by Elsevier B.V. All rights reserved.

\section{Introduction}

Ammoxidation of 3-picoline (3-PIC) to nicotinonitrile (NN) is an important reaction towards the production of niacin. The latter is a component found in many multivitamins, foods, and soft drinks. Niacin is also used as a feed additive for domestic and farm animals; more than $60 \%$ of the niacin produced is consumed by poultry, ruminants, fish, and pets [1]. Niacin is also used as a precursor for the manufacture of several commercial compounds such as cancer drugs, antibacterial agents, and pesticides.

Supported vanadium oxide catalysts are promising catalyst systems for ammoxidation reactions of organic compounds and oxidative dehydrogenation of light alkanes [2-4]. The catalytic properties, such as activity and selectivity, are highly influenced by the characteristics (e.g., constituent elements, structure) of the support that consequently impacts on the interactive species generated on the support surface [5-8]. Of the many supports that have been extensively studied for ammoxidation reactions, $\mathrm{SiO}_{2}$ is the most widely employed because of its high surface area and high stability at elevated temperatures [9]. The use of non-conventional $\mathrm{MgF}_{2}$-supported $\mathrm{V}_{2} \mathrm{O}_{5}$ catalysts has also been reported [10-12]. For instance, $\mathrm{MgF}_{2}$-supported vanadia catalysts with a 15.7 wt $\%$ vanadia loading showed very high activity (>90\%) and selectivity (>95\%) towards the ammoxidation of 3-PIC. $\mathrm{TiO}_{2}$, in particular anatase titania, has also been reported as an excellent support for the ammoxidation of 3-PIC to NN $[13,14]$. For example, $\mathrm{TiO}_{2}$-supported vana-

\footnotetext{
*Corresponding author. Tel/Fax: +86-25-52090612; E-mail: xiaogm@seu.edu.cn This work was supported by the National Natural Science Foundation of China (21276050) and the National Key Technology R\&D Program (2012BAD32B03).

DOI: 10.1016/S1872-2067(12)60650-0 | http://www.sciencedirect.com/science/journal/18722067 | Chin. J. Catal., Vol. 34, No. 10, October 2013
} 
dium phosphorus oxide (VPO) catalysts achieved a high conversion $(\sim 100 \%)$ and a high NN yield (83\%). The high performance of the supported catalyst was attributed to the altered acid properties of the catalyst as a result of the strong interaction between the titania support and the VPO catalyst [13]. Niobia is another good support for ammoxidation reactions $[15,16]$. Both niobium and vanadium are expected to have similar properties as they belong to the same group of the periodic table. However, niobium is less prone to reduction than vanadium, often leading to low selectivity in selective oxidation reactions.

Bulk chromium vanadates have also been studied for the ammoxidation of 2-methylpyrazine to 2-cyanopyrazine. Although a high conversion ( $100 \%)$ was achieved, the selectivity was only $40 \%$ [17]. Our previous studies showed that both the selectivity and activity of the catalyst for the ammoxidation of 3-PIC could be tailored by adjusting the $\mathrm{Cr} / \mathrm{V}$ molar ratio [18]. An optimum yield was obtained at a $\mathrm{Cr} / \mathrm{V}$ molar ratio of 0.4 .

To our knowledge, investigations of the influence of supports on vanadium-chromium oxide (VCrO) catalysts are limited. Hence in this study, incipient wetness impregnation techniques were employed to synthesize a range of supported $\mathrm{VCrO}$ catalysts. The investigated supports include $\mathrm{Nb}_{2} \mathrm{O}_{5}, \mathrm{MgF}_{2}, \mathrm{TiO}_{2}$, and $\mathrm{SiO}_{2}$. The catalytic performance of the supported catalysts for the ammoxidation of 3-PIC to NN was assessed and correlated with the physicochemical properties of the supported catalysts.

\section{Experimental}

\subsection{Catalyst preparation}

Bulk and supported catalysts with the $\mathrm{V}_{2} \mathrm{O}_{5}$ : $\mathrm{CrO}_{3}$ :support mass ratio of 1:0.44:4.90 were prepared in an aqueous medium by incipient wetness impregnation. $\mathrm{SiO}_{2}$ (particle, $474 \mathrm{~m}^{2} / \mathrm{g}$ ), $\mathrm{MgF}_{2}$ (powder, $44 \mathrm{~m}^{2} / \mathrm{g}$ ), $\mathrm{TiO}_{2}$ (powder, anatase, $102 \mathrm{~m}^{2} / \mathrm{g}$ ), and $\mathrm{Nb}_{2} \mathrm{O}_{5}$ (powder, $11 \mathrm{~m}^{2} / \mathrm{g}$ ) were used as supports; $\mathrm{V}_{2} \mathrm{O}_{5}$ and $\mathrm{CrO}_{3}$ were used as sources of vanadia and chromia, respectively. Required amounts of $\mathrm{V}_{2} \mathrm{O}_{5}$ and $\mathrm{CrO}_{3}$ were dissolved in an aqueous oxalic acid solution that was then introduced into the various supports. The samples were dried at $110{ }^{\circ} \mathrm{C}$ for $10 \mathrm{~h}$ and then calcined at $500{ }^{\circ} \mathrm{C}$ for $6 \mathrm{~h}$ in air. Finally, all samples, except $\mathrm{VCrO} / \mathrm{SiO}_{2}$, were pressed and sieved to a desired fraction (20-40 mesh). The $\mathrm{VCrO} / \mathrm{SiO}_{2}$ sample was directly sieved to 20-40 mesh.

\subsection{Catalyst characterization}

X-ray diffraction (XRD) patterns of the samples were recorded on a Bruker D8 Focus X-ray diffractometer using $\mathrm{Cu} K_{\alpha}$ radiation and a nickel filter $(\lambda=1.5406 \AA)$ at a respective voltage of $40 \mathrm{kV}$ and current of $40 \mathrm{~mA}$. The BET surface area and pore characteristics of the samples were measured on a Beishide $3 \mathrm{H}-2000$ analyzer. Prior to analysis at $-196{ }^{\circ} \mathrm{C}$, the samples were degassed at $300{ }^{\circ} \mathrm{C}$ for $3 \mathrm{~h}$. $\mathrm{NH}_{3}$ temperatureprogrammed desorption ( $\mathrm{NH}_{3} \mathrm{TPD}$ ) experiments were carried out on a Micromeritics AutoChem II 2920 automated catalyst characterization system. Prior to the $\mathrm{NH}_{3}$-TPD tests, the samples were pre-treated with $\mathrm{He}$ at $150{ }^{\circ} \mathrm{C}$ for $1 \mathrm{~h}$ to remove adsorbed water. After cooling to $100{ }^{\circ} \mathrm{C}, \mathrm{NH}_{3}$ was injected until saturation. The temperature was then raised to $500{ }^{\circ} \mathrm{C}$ at a rate of $10{ }^{\circ} \mathrm{C} / \mathrm{min}$. The desorbed products were monitored by a thermal conductor detector (TCD). Temperature-programmed reduction (TPR) experiments were also carried out on the Micromeritics AutoChem II 2920. The sample (150 mg) was loaded into a U-shaped quartz tube and dried at $150{ }^{\circ} \mathrm{C}$ for $1 \mathrm{~h}$. The sample was then cooled to room temperature before being reduced in a $10 \% \mathrm{H}_{2} / \mathrm{Ar}$ flow at a ramping rate of $10{ }^{\circ} \mathrm{C} / \mathrm{min}$ from 100 to $700^{\circ} \mathrm{C}$. The components of the gas after reduction were monitored by TCD.

\subsection{Catalyst tests}

The ammoxidation of 3-PIC was carried out in a fixed-bed, stainless steel reactor at atmospheric pressure. The catalyst ( 5 g) was first diluted with an equal amount of acid-base washed quartz sand (20-40 mesh) to minimize the temperature gradient for each test. A thermocouple was inserted in the middle of the catalyst bed to measure the reaction temperature. The flow rates of the reactant gases $\left(\mathrm{NH}_{3}\right.$ and air) were adjusted by mass flow controllers. The liquid feed comprising 3-PIC and $\mathrm{H}_{2} \mathrm{O}$ (molar ratio of 3-PIC: $\mathrm{H}_{2} \mathrm{O}=1: 5$ ) was metered by a syringe pump and vaporized in a preheating zone located at the top of the catalyst bed. The molar ratio of the reactant feed mixture was 3-PIC:air: $\mathrm{NH}_{3}: \mathrm{H}_{2} \mathrm{O}=1: 22: 4.5: 5$ and the flow rate of 3-PIC was maintained at $14.7 \mathrm{mmol} / \mathrm{h}$. The reaction was performed at $310-400{ }^{\circ} \mathrm{C}$, depending on the support studied. The products were collected in a cold trap and analyzed by a gas chromatograph (GC) equipped with a flame ionization detector (FID). Conversion of 3-PIC and selectivity for NN were calculated on a carbon basis.

\section{Results and discussion}

\section{1. $N_{2}$ adsorption-desorption results}

The specific surface area and pore volume of the supports and the corresponding supported VCrO samples are listed in Table 1. The materials featured a wide range of surface areas from 3 to $474 \mathrm{~m}^{2} / \mathrm{g}$. A reduction in specific surface area was noted in the supported catalysts relative to that of the supports, suggesting the onset of pore blockage in the support by crystallites of vanadia and chromia. This was evidenced by XRD analyses (Fig. 1) and the reduced pore volumes (Table 1). The specific surface areas of the bulk $\mathrm{VCrO}$ and $\mathrm{VCrO} / \mathrm{Nb}_{2} \mathrm{O}_{5}$ catalysts were only 3 and $7 \mathrm{~m}^{2} / \mathrm{g}$, respectively.

\subsection{XRD results}

XRD patterns of the materials are shown in Fig. 1. The diffractogram of the bulk catalyst showed more reflections typical of VCrO than the one obtained for the supported catalysts. The bulk catalyst consisted of orthorhombic $\mathrm{V}_{2} \mathrm{O}_{5}$ (JCPDS No. 9-387), with the corresponding diffraction peaks at $2 \theta=20.2^{\circ}$ 
Table 1

Properties of supports and their supported VCrO catalysts.

\begin{tabular}{|c|c|c|c|c|c|}
\hline \multirow[b]{2}{*}{ Sample } & \multirow{2}{*}{$\begin{array}{c}A_{\text {BET }} \\
\left(\mathrm{m}^{2} / \mathrm{g}\right)\end{array}$} & \multirow{2}{*}{ 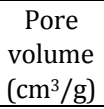 } & \multirow{2}{*}{$\begin{array}{c}\mathrm{H}_{2} \text { con- } \\
\text { sumption } \\
(\mathrm{mmol} / \mathrm{g})\end{array}$} & \multicolumn{2}{|r|}{ Acidity } \\
\hline & & & & $(\mathrm{mmol} / \mathrm{g})$ & $\left(10^{-3} \mathrm{mmol} / \mathrm{m}^{2}\right)$ \\
\hline $\mathrm{Nb}_{2} \mathrm{O}_{5}$ & 11 & 0.02 & - & - & - \\
\hline $\mathrm{MgF}_{2}$ & 44 & 0.16 & - & - & - \\
\hline $\mathrm{TiO}_{2}$ & 102 & 0.29 & - & - & - \\
\hline $\mathrm{SiO}_{2}$ & 474 & 1.04 & - & - & - \\
\hline $\mathrm{VCrO} / \mathrm{Nb}_{2} \mathrm{O}_{5}$ & 7 & 0.01 & 1.32 & $\sim 0$ & $\sim 0$ \\
\hline $\mathrm{VCrO} / \mathrm{MgF}_{2}$ & 23 & 0.12 & 1.75 & 0.02 & 0.07 \\
\hline $\mathrm{VCrO} / \mathrm{TiO}_{2}$ & 59 & 0.23 & 2.69 & 0.06 & 1.07 \\
\hline $\mathrm{VCrO} / \mathrm{SiO}_{2}$ & 276 & 0.61 & 2.53 & 0.33 & 1.19 \\
\hline Bulk VCrO & 3 & 0.02 & 5.08 & $\sim 0$ & $\sim 0$ \\
\hline
\end{tabular}

(001), $26.2^{\circ}(110)$, and $31.2^{\circ}$ (400), and orthorhombic $\mathrm{CrVO}_{4}$-III (JCPDS No. 38-1376), with the associated major diffraction peaks at $2 \theta=21.6^{\circ}(020), 24.2^{\circ}(111), 26.2^{\circ}(120)$, $32.1^{\circ}(002), 35.8^{\circ}(211)$, and $36.6^{\circ}(031)$. The supported catalysts all featured weak reflections of VCrO; also, the intensity of diffraction peaks was slightly weaker than that of the bare supports, suggesting that the structure of the supports was well retained. The $\mathrm{VCrO} / \mathrm{Nb}_{2} \mathrm{O}_{5}$ catalyst exhibited diffraction peaks similar to those of the corresponding $\mathrm{Nb}_{2} \mathrm{O}_{5}$ support, indicating the presence of small VCrO crystallites that were well dispersed within the supported matrix. In contrast, a weak band at $2 \theta=$ $28^{\circ}(-220)$, corresponding to monoclinic $\mathrm{CrVO}_{4}$-I (JCPDS No. 51-31), was detected in the $\mathrm{SiO}_{2}-$ and $\mathrm{TiO}_{2}$-supported catalysts. In addition to the typical reflections, corresponding to the $\mathrm{MgF}_{2}$ support, $\mathrm{MgF}_{2}$-supported catalyst showed weak diffraction peaks at $2 \theta=24.2^{\circ}, 26.2^{\circ}, 32.1^{\circ}, 35.8^{\circ}$, and $36.6^{\circ}$ that were attributed to the above-mentioned $\mathrm{CrVO}_{4}$-III phase. Based on these findings, monoclinic $\mathrm{CrVO}_{4}$ preferentially forms within supports with large surface areas (i.e., $\mathrm{SiO}_{2}$ and $\mathrm{TiO}_{2}$ ) whereas formation of orthorhombic $\mathrm{CrVO}_{4}$ preferentially occurs within supports with small surface areas (i.e., $\mathrm{MgF}_{2}$ ). It is worth noting that the $\mathrm{Nb}_{2} \mathrm{O}_{5}$-supported catalyst that comprised small-sized VCrO crystallites, as suggested from XRD analysis, featured the

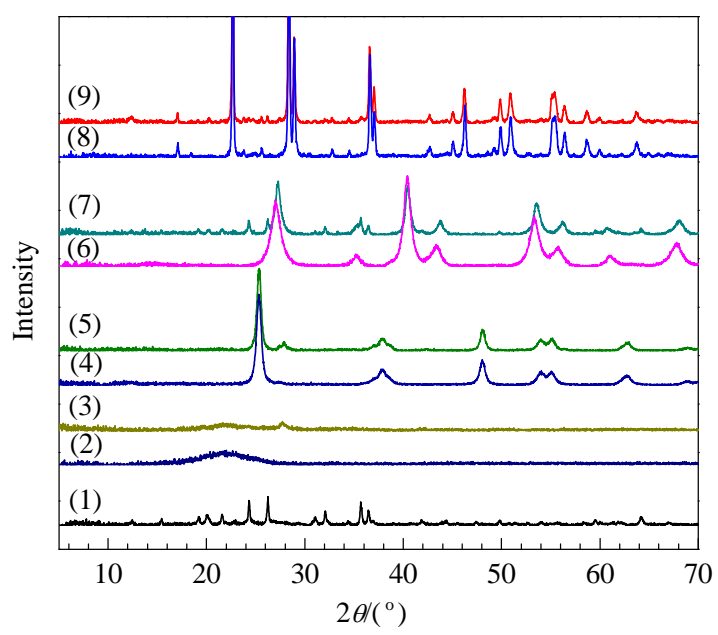

Fig. 1. XRD patterns of different samples. (1) Bulk VCrO; (2) $\mathrm{SiO}_{2}$; (3) $\mathrm{VCrO} / \mathrm{SiO}_{2}$; (4) $\mathrm{TiO}_{2}$; (5) $\mathrm{VCrO} / \mathrm{TiO}_{2}$; (6) $\mathrm{MgF}_{2}$; (7) $\mathrm{VCrO} / \mathrm{MgF}_{2}$; (8) $\mathrm{Nb}_{2} \mathrm{O}_{5}$; (9) $\mathrm{VCrO} / \mathrm{Nb}_{2} \mathrm{O}_{5}$.

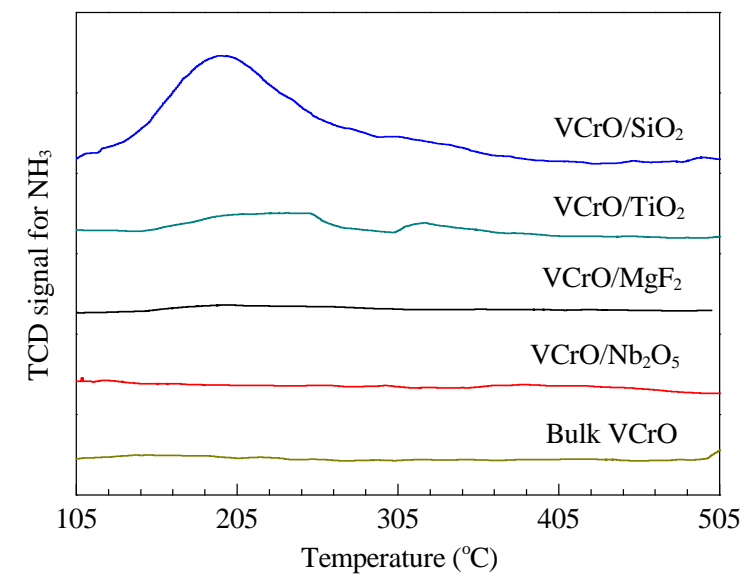

Fig. 2. $\mathrm{NH}_{3}$-TPD profiles of the bulk and supported VCrO catalysts.

lowest surface area. Niobium, vanadium, and chromium are expected to have similar properties because of their close location in the periodic table. The active contents on the $\mathrm{Nb}_{2} \mathrm{O}_{5}$ support may be amorphous orthorhombic $\mathrm{CrVO}_{4}$ for its surface area was the smallest among the supports. In general, most $\mathrm{VCrO}$ contents are amorphous on the surface of different supports.

\section{3. $\mathrm{NH}_{3}-\mathrm{TPD}$ results}

$\mathrm{NH}_{3}$-TPD studies were performed to assess the acidic properties of the catalysts. Surface acidity is an important parameter that influences the selectivity of ammoxidation catalysts. $\mathrm{NH}_{3}$-TPD profiles of the bulk and supported VCrO catalysts are shown in Fig. 2. The calculated amount of desorbed $\mathrm{NH}_{3}$ (mmol/g) is presented in Table 1. Surface area normalized acidity data $\left(\mathrm{mmol} / \mathrm{m}^{2}\right)$ are also presented to allow comparison between the catalysts that feature differing surface areas. As suggested from Fig. 2, both the bulk and $\mathrm{Nb}_{2} \mathrm{O}_{5}$-supported $\mathrm{VCrO}$ catalysts possessed negligible acidic surface character based on the relatively flat $\mathrm{NH}_{3}$ desorption curves. $\mathrm{SiO}_{2-}$ and $\mathrm{MgF}_{2}$-supported catalysts displayed only one desorption peak at $190-250{ }^{\circ} \mathrm{C} . \mathrm{VCrO} / \mathrm{TiO}_{2}$ catalyst featured an additional peak at $330{ }^{\circ} \mathrm{C}$ that corresponds to moderate acid sites (the peak area amounted to $25 \%$ of the profile curve area). The number of surface acid sites (mmol/g) of the catalysts increased in the following order: bulk $\mathrm{VCrO} \approx \mathrm{VCrO} / \mathrm{Nb}_{2} \mathrm{O}_{5}<\mathrm{VCrO} / \mathrm{MgF}_{2}<$ $\mathrm{VCrO} / \mathrm{TiO}_{2}<\mathrm{VCrO} / \mathrm{SiO}_{2}$. A similar trend was obtained for the surface acid site density $\left(\mathrm{mmol} / \mathrm{m}^{2}\right)$. In general, supported catalysts with monoclinic $\mathrm{CrVO}_{4}$ characteristics $\left(\mathrm{VCrO} / \mathrm{TiO}_{2}\right.$ and $\mathrm{VCrO} / \mathrm{SiO}_{2}$ ) had a higher acid site density than that featured by supported catalysts with orthorhombic $\mathrm{CrVO}_{4}$ characteristics (bulk $\mathrm{VCrO}, \mathrm{VCrO} / \mathrm{Nb}_{2} \mathrm{O}_{5}$, and $\mathrm{VCrO} / \mathrm{MgF}_{2}$ ). In addition to the varying acid properties of the different supports, the intrinsic higher acid property of monoclinic $\mathrm{CrVO}_{4}$ could contribute to the acid properties observed for the supported catalysts $[19,20]$.

\section{4. $\mathrm{H}_{2}$-TPR results}




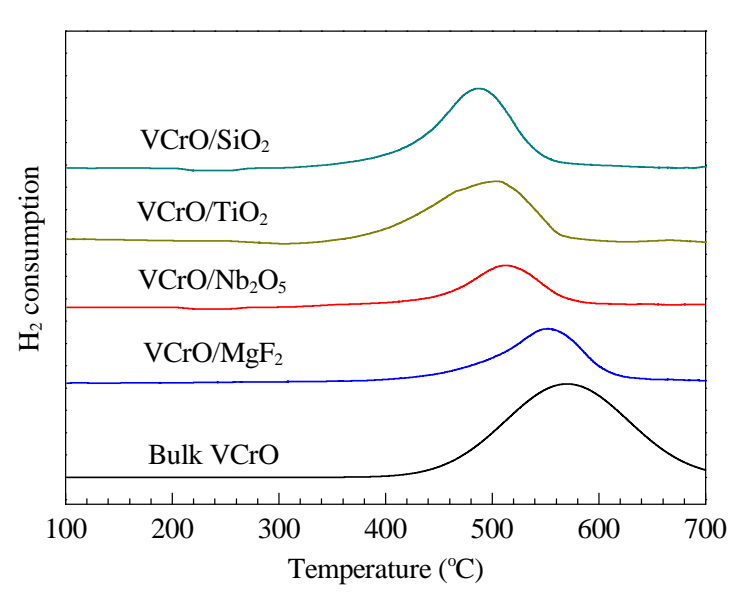

Fig. 3. $\mathrm{H}_{2}$-TPR profiles of the bulk and supported VCrO catalysts.

$\mathrm{H}_{2}$-TPR profiles of the bulk and supported $\mathrm{VCrO}$ catalysts are shown in Fig. 3. Partial reduction of $\mathrm{Nb}_{2} \mathrm{O}_{5}$ is reported to occur at $1000{ }^{\circ} \mathrm{C}$ [21]. Also, under the present conditions, reduction of $\mathrm{MgF}_{2}, \mathrm{TiO}_{2}$, and $\mathrm{SiO}_{2}$ was not observed. As discussed in Section 3.2, $\mathrm{Cr}$ and $\mathrm{V}$ species co-exist as $\mathrm{CrVO}_{4}$ and $\mathrm{V}_{2} \mathrm{O}_{5}$ where the oxidation states of $\mathrm{V}$ and $\mathrm{Cr}$ are +5 and +3 , respectively. The single peak observed in the TPR profiles indicated the onset of reduction of vanadia from $\mathrm{V}^{5+}$ to $\mathrm{V}^{3+}$ [4]. Compared with the bulk VCrO catalyst, the reduction of vanadia species in the supported catalysts became easier, as indicated from the lower peak temperature. The lower reducibility featured in the bulk catalyst was attributed to bulk diffusion limitations as a result of larger crystallites when compared with those present in the supported catalysts. The reducibility of the catalysts in terms of reduction temperature decreased in the order: $\mathrm{VCrO} / \mathrm{SiO}_{2}\left(490{ }^{\circ} \mathrm{C}\right)>\mathrm{VCrO} / \mathrm{TiO}_{2}\left(502{ }^{\circ} \mathrm{C}\right)>\mathrm{VCrO} / \mathrm{Nb}_{2} \mathrm{O}_{5}(512$ $\left.{ }^{\circ} \mathrm{C}\right)>\mathrm{VCrO} / \mathrm{MgF}_{2}\left(553{ }^{\circ} \mathrm{C}\right)>$ bulk VCrO $\left(570{ }^{\circ} \mathrm{C}\right)$. The results suggest that the $\mathrm{V}$ species in $\mathrm{CrVO}_{4}$-III is more stable against reduction than that in $\mathrm{CrVO}_{4}$-I [20]. The amount of $\mathrm{H}_{2}$ consumed during the TPR studies was also employed to evaluate the number of surface active sites on the catalysts. In general, the number of surface active sites increased as the surface area of the supported catalysts increased. However, it was noted that both $\mathrm{VCrO} / \mathrm{TiO}_{2}$ and $\mathrm{VCrO} / \mathrm{SiO}_{2}$ catalysts featured comparable number of active sites despite the lower surface area of the $\mathrm{TiO}_{2}$-suported catalyst. This indicates that the interaction between $\mathrm{VCrO}$ and the $\mathrm{TiO}_{2}$ support differed from other $\mathrm{VCrO}$ catalysts, and that there was a surface enrichment of the active phase on the $\mathrm{TiO}_{2}$ support. Among the catalysts prepared, the bulk catalyst had the largest amount of vanadium-chromium components that translated to the highest number of active sites.

\subsection{Catalysis studies}

Figure 4 depicts the dependence of 3-PIC conversion over the catalysts on the reaction temperature. $\mathrm{The} \mathrm{VCrO} / \mathrm{TiO}_{2}$ catalyst displayed the highest activity: a maximum conversion $(\sim 100 \%)$ was achieved at a relatively low temperature $(320$ ${ }^{\circ} \mathrm{C}$ ). In contrast, the other catalysts required higher tempera-

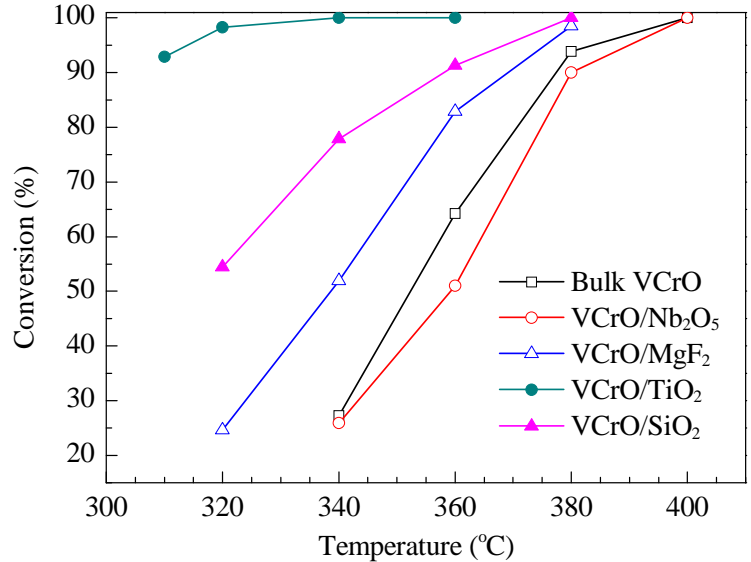

Fig. 4. 3-Picoline conversion dependence on reaction temperature over different $\mathrm{VCrO}$ catalysts.

tures to achieve the same conversion. The activity decreased in the order $\mathrm{VCrO} / \mathrm{TiO}_{2}>\mathrm{VCrO} / \mathrm{SiO}_{2}>\mathrm{VCrO} / \mathrm{MgF}_{2}>$ bulk $\mathrm{VCrO}>$ $\mathrm{VCrO} / \mathrm{Nb}_{2} \mathrm{O}_{5}$

The Mars-van Krevelen mechanism has been widely employed to describe ammoxidation reactions involving vanadium catalysts as the redox-active sites [11,22]. During the reaction, the catalyst (vanadium) is partly reduced by the removal of oxygen from the lattice. The vacancies are subsequently replenished by gas phase oxygen. Therefore, the redox properties strongly influence the catalytic performance. According to a study by Radheshyam et al. [23], the activation energy of the reduction step is almost three times higher than that of the reoxidization step in the ammoxidation of 3-PIC over $\mathrm{V}_{2} \mathrm{O}_{5} / \mathrm{ZrO}_{2}$ catalyst. These findings indicated that the more reducible the vanadium in the catalyst is, the more active the catalyst is. Thus, it can be inferred that both the number of active sites and the reducibility of vanadium in the catalysts are key parameters that determine the conversion performance of 3-PIC. As discussed earlier, the bulk VCrO catalyst had the highest number of active sites followed by $\mathrm{VCrO} / \mathrm{TiO}_{2}$, $\mathrm{VCrO} / \mathrm{SiO}_{2}$, $\mathrm{VCrO} / \mathrm{MgF}_{2}$, and $\mathrm{VCrO} / \mathrm{Nb}_{2} \mathrm{O}_{5}$, as indicated by the $\mathrm{H}_{2}$ consumption values in Table 1 . In contrast, $\mathrm{VCrO} / \mathrm{SiO}_{2}$ and $\mathrm{VCrO} / \mathrm{TiO}_{2}$ catalysts displayed higher reducibility properties than $\mathrm{VCrO} / \mathrm{Nb}_{2} \mathrm{O}_{5}, \mathrm{VCrO} / \mathrm{MgF}_{2}$, and bulk $\mathrm{VCrO}$ as discussed earlier. The performance of the catalysts was consistent with these trends. For instance, the high activity of the $\mathrm{VCrO} / \mathrm{TiO}_{2}$ catalyst was attributed to its relatively easy reducibility and a high number of active sites. In contrast, the $\mathrm{VCrO} / \mathrm{Nb}_{2} \mathrm{O}_{5}$ catalyst, which was difficult to reduce and featured a low number of active sites, displayed the lowest catalytic activity. The higher conversion at elevated temperatures indicated either the formation of active phases as intermediate compounds or the increased intrinsic activity of the existing active sites at the higher temperatures [11].

The effect of reaction temperature on selectivity for NN is shown in Fig. 5. Although the influence of reaction temperature on selectivity was minimal, the following observations were noted. The selectivity for $\mathrm{NN}$ of $\mathrm{TiO}_{2-}, \mathrm{MgF}_{2}$, and $\mathrm{Nb}_{2} \mathrm{O}_{5}$-supported $\mathrm{VCrO}$ catalysts initially increased with increasing tem- 


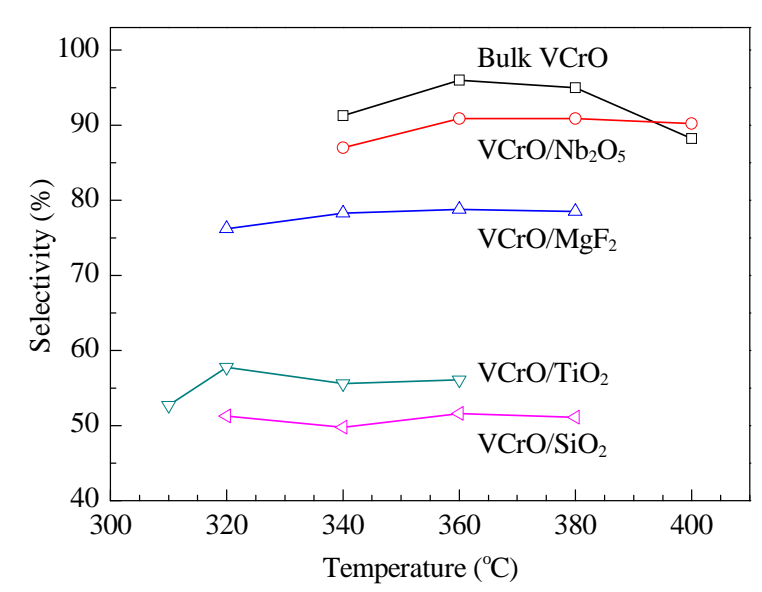

Fig. 5. Selectivity for nicotinonitrile dependence on reaction temperature.

perature before reaching a constant value whereas the NN selectivity of bulk catalyst increased to a maximum value with an initial increase in temperature prior to declining with further increase in temperature. In comparison, the selectivity of $\mathrm{SiO}_{2}$-supported catalyst, which was calculated as $\sim 56 \%$, was independent of the reaction temperature. Unlike the reaction temperature, surface acidity of the catalyst had a greater influence on the selectivity; an inverse correlation between selectivity and surface acidity was noted in the catalysts. For instance, the bulk and $\mathrm{Nb}_{2} \mathrm{O}_{5}$-supported catalysts, which featured negligible surface acid character, displayed the highest selectivity. Although both $\mathrm{VCrO} / \mathrm{TiO}_{2}$ and $\mathrm{VCrO} / \mathrm{MgF}_{2}$ catalysts displayed comparable surface acidities, the selectivity of the former was lower. This was believed to be due to the presence of moderate acid sites on the $\mathrm{VCrO} / \mathrm{TiO}_{2}$ catalysts, as discussed earlier. Stronger surface acidity is likely to favor stronger interactions between the acid sites and the aromatic product, thereby hindering its fast desorption from the catalyst surface, consequently making it prone for total oxidation. Likewise, higher surface acidity is disadvantageous as ammonia may neutralize the acid sites, thereby lowering the number of active sites required for the process, subsequently promoting oxidation and reducing NN selectivity. These findings clearly indicated that low surface acidity (amount and strength) was preferred for ammoxidation of 3-PIC. These findings are consistent with the observations reported by other researchers $[24,25]$.

In general, increasing the reaction temperature enhanced the activity of the catalyst while maintaining high selectivity performance. The following catalysts achieved the best NN yield at the corresponding temperatures: bulk VCrO ( $\mathrm{NN}$ yield = $89.2 \%$, NN selectivity $=95 \%$, and 3 -PIC conversion $=93.9 \%$ at $380{ }^{\circ} \mathrm{C}$ ) and $\mathrm{VCrO} / \mathrm{Nb}_{2} \mathrm{O}_{5}$ ( $\mathrm{NN}$ yield $=90.2 \%$, NN selectivity $=$ $90.2 \%$, and 3-PIC conversion $=100 \%$ at $400{ }^{\circ} \mathrm{C}$ ).

\section{Conclusions}

Highly efficient ammoxidation catalysts of bulk and $\mathrm{Nb}_{2} \mathrm{O}_{5-}$, $\mathrm{MgF}_{2}$, $\mathrm{TiO}_{2-}$, and $\mathrm{SiO}_{2}$-supported $\mathrm{VCrO}$ were prepared via an incipient wetness impregnation method. XRD results showed that though there were small crystallites on $\mathrm{MgF}_{2}, \mathrm{TiO}_{2}$, and $\mathrm{SiO}_{2}$ support, the $\mathrm{VCrO}$ contents were mostly amorphous on the various supports. The catalytic activity and selectivity of the catalysts were strongly dependent on the catalyst reducibility and surface acidity. Enhanced catalytic activity was possible by increasing the reaction temperature. $\mathrm{VCrO} / \mathrm{Nb}_{2} \mathrm{O}_{5}$ catalyst achieved the highest nicotinonitrile yield $(90.2 \%)$ at $400{ }^{\circ} \mathrm{C}$.

\section{References}

[1] Martin A, Kalevaru V N. ChemCatChem, 2010, 2: 1504

[2] Narayana K V, Masthan S K, Rao V V, Raju B D, Rao P K. Catal Commun, 2002, 3: 173

[3] Lu H F, Zhou Y, Huang H F, Liu H Y, Chen Y F. Chin J Catal (卢晗锋, 周瑛, 黄海风, 刘华彦, 陈银飞. 催化学报), 2005, 26: 101

[4] Dai H X, Bell A T, Iglesia E.J Catal, 2004, 221: 491

[5] Narayana K V, Raju B D, Masthan S K, Rao V V, Rao P K, Martin A.J Mol Catal A, 2004, 223: 321

[6] Bautista F M, Campelo J M, Luna D, Luque J, Marinas J M. Appl Catal A, 2007, 325: 336

[7] Zhao C L, Wachs I E. Catal Today, 2006, 118: 332

[8] Yang S W, Iglesia E, Bell A T.J Phys Chem B, 2005, 109: 8987

[9] Reddy K M, Lingaiah N, Nagaraju P, Prasad P S S, Suryanarayana I. Catal Lett, 2008, 122: 314

[10] Kalevaru V N, Raju B D, Rao V V, Martin A. Catal Commun, 2008, 9 : 715

[11] Kalevaru V N, Raju B D, Rao V V, Martin A. Appl Catal A, 2009, 352: 223

\section{Graphical Abstract}

Chin. J. Catal., 2013, 34: 1833-1838 doi: 10.1016/S1872-2067(12)60650-0

Effect of supports on the structure and activity of vanadium-chromium oxide catalysts for ammoxidation of 3-picoline

Feng Jiang, Shengcai Deng, Lei Niu, Guomin Xiao* Southeast University; Nanjing University

Highly efficient vanadium-chromium oxide catalysts for ammoxidation of 3-picoline have been prepared. The acidity and reducibility had great influence on the catalytic activity and selectivity.

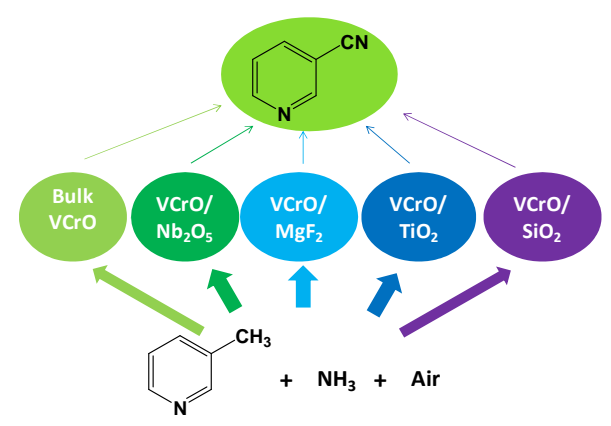


[12] Kalevaru V N, Raju B D, Masthan S K, Rao V V, Rao P K. Catal Lett, 2002, 84: 27

[13] Kalevaru V N, Madaan N, Martin A. Appl Catal A, 2011, 391: 52

[14] Chary K V R, Kishan G, Lakshmi K S, Ramesh K S. Langmuir, 2000, 16: 7192

[15] Chary K V R, Kumar C P, Reddy K R, Bhaskar T, Rajiah T. Catal Commun, 2002, 3: 7

[16] Chary K V R, Kishan G, Kumar C P, Sagar G V, Niemantsverdriet ] W. Appl Catal A, 2003, 245: 303

[17] Dhachapally N, Kalevaru V N, Radnik J, Martin A. Chem Commun, 2011, 47: 8394

[18] Jiang F, Wei R P, Gao L J, Xiao G M, Niu L. Res Chem Intermed, 2013, 39: 1353
[19] Song Z X, Matsushita T, Shishido T, Takehira K. J Catal, 2003, 218: 32

[20] Shishido T. J Jpn Petrol Inst, 2011, 54: 225

[21] Chary K V R, Bhaskar T, Kishan G, Reddy K R. J Phys Chem B, 2001, 105: 4392

[22] Andersson A, Lundin S T.J Catal, 1979, 58: 383

[23] Radheshyam A, Reddy V S, Dwivedi R, Prasad R. Can J Chem Eng, 2005, 83: 274

[24] Janke C, Radnik J, Bentrup U, Martin A, Bruckner A. ChemCatChem, 2009, 1: 485

[25] Roy S K, Dutta P, Nandi L N, Yadav S N, Mondal T K, Ray S C, Mitra S, Samuel P.J Mol Catal A, 2004, 223: 211

\title{
载体对钒铬氧化物催化剂结构及催化3-甲基吡啶氨氧化反应活性的影响
}

\author{
姜 枫 ${ }^{\mathrm{a}}$, 邓生财 ${ }^{\mathrm{b}}$, 牛 䂞 ${ }^{\mathrm{a}}$, 肖国民 民 $^{\mathrm{a}}{ }^{*}$ \\ a东南大学化学化工学院, 江苏南京211189 \\ b南京大学化学化工学院, 介观化学教育部重点实验室, 江苏省纳米技术重点实验室, 江苏南京210093
}

摘要: 通过等体积浸渍法制备了 $\mathrm{Nb}_{2} \mathrm{O}_{5}, \mathrm{MgF}_{2}, \mathrm{TiO}_{2}$ 和 $\mathrm{SiO}_{2}$ 负载和未负载的钒铬氧化物催化剂, 并应用 $\mathrm{X}$ 射线衍射、 $\mathrm{N}_{2}$ 吸附-脱附、 $\mathrm{H}_{2}$ 程序升温还原和 $\mathrm{NH}_{3}$ 程序升温脱附对催化剂进行了表征. 结果表明, 催化剂比表面积较大时有利于 $\mathrm{CrVO}_{4}-\mathrm{I}$ (单斜)的生成, 比表 面积较小则有利于 $\mathrm{CrVO}_{4}$-III (斜方)的生成. 在 $310-400{ }^{\circ} \mathrm{C}$ 下 3 -甲基吡啶氨氧化制备3-氰基吡啶反应中, 具有较高催化活性的催化 剂与 $\mathrm{V}$ 物种还原性较高和表面活性位数量较多有关; 而高的3-氰基吡啶选择性则与催化剂表面较低的酸性密切相关. 升高反应温 度可大幅度提高催化剂的活性, 且其选择性基本不变.

关键词：氨氧化; 3-甲基吡啶; 3-氰基吡啶；载体；钒铬氧化物

收稿日期: 2013-06-07. 接受日期: 2013-07-02. 出版日期: 2013-10-20.

*通讯联系人. 电话/传真: (025)52090612; 电子信箱: xiaogm@seu.edu.cn

基金来源：国家自然科学基金(21276050); 国家科技支撑计划(2012BAD32B03).

本文的英文电子版由Elsevier出版社在ScienceDirect上出版(http://www.sciencedirect.com/science/journal/18722067). 